\title{
Study to Establish Cost Projections for Production of Redox Chemicals
}

J. F. Walther, C. C. Greco, R. N. Rusinko, and A. L. Wadsworth, 3rd

Syracuse Research Laboratory

Allied Chemical Company

Allied Corporation

\section{LIBRARY COPY}

November 1982

[ied 1983

LANGLEY RESEARCH CENTER

LIBRARY, NASA

HAMPTON, VIRGINIA

Prepared for

NATIONAL AERONAUTICS AND SPACE ADMINISTRATION

Lewis Research Center

Under Contract DEN 3-250

for

U.S. DEPARTMENT OF ENERGY

Conservation and Renewable Energy

Division of Energy Storage Systems 


\section{DISCLAIMER}

This report was prepared as an account of work sponsored by an agency of the United States Government. Nelther the United States Government nor any agency thereof, nor any of their employees, makes any warranty, express or implied, or assumes any legal liabllity or responsibility for the accuracy, completeness, or usefulness of any information, apparatus, product, or process disclosed, or represents that its use would not infringe privately owned rights. Reference herein to any specific commercial product, process, or service by trade name, trademark, manufacturer, or otherwise, does not necessarily constltute or imply its endorsement, recommendation, or favoring by the United States Government or any agency thereof. The vlews and opinions of authors expressed herein do not necessarily state or reflect those of the United States Government or any agency thereof.

Printed in the United States of America

Available from

National Technical Information Service

U.S. Department of Commerce

5285 Port Royal Road

Springfield, VA 22161

NTIS price codes 1

Printed copy: A03

Microfiche copy: A01

1 Codes are used for pricing all publications. The code is determined by the number of pages in the publication. Information pertaining to the pricing codes can be found In the current issues of the following publications, which are generally available in most libraries: Energy Research Abstracts (ERA); Government Reports Announcements and Index (GRA and I); Scientific and Technical Abstract Reports (STAR); and publication, NTIS-PR-360 avallable from NTIS at the above address. 
DOE/NASA/0250-1

NASA CR-167881

\section{Study to Establish Cost Projections for Production of Redox Chemicals}

J. F. Walther, C. C. Greco, R. N. Rusinko, and $A$. L. Wadsworth, 3rd

Syracuse Research Laboratory

Allied Chemical Company

Allied Corporation

Solvay, New York 13209

November 1982

Prepared for

National Aeronautics and Space Administration

Lewis Research Center

Cleveland, Ohio 44135

Under Contract DEN 3-250

for

U.S. DEPARTMENT OF ENERGY

Conservation and Renewable Energy

Division of Energy Storage Systems

Washington, D.C. 20545

Under Interagency Agreement DE-AI04-80AL12726 
This Page Intentionally Left Blank 
TABLE OF CONTENTS

Page

SUMMARY.............................. 1

INTRODUCTION.............................. 2

PROCESS DESCRIPTIONS...................... 6

Reductive Chlorination of Chrome Ore.......... 6

Chlorination of Prereduced Chrome Ore......... 8

Electrolytic Reduction of Sodium Chromate..... 11

Methanol Reduction of Sodium Chromate......... 13

RESULTS AND DISCUSSION OF TASK 1

PRELIMINARY COST COMPARISON................. 15

Task 1 Cost Summary....................... 15

Discussion of Task 1 Results................. 17

RESULTS AND DISCUSSION OF TASK 2

EXPANDED MANUFACTURING COST ESTIMATE.......... 23

CONCLUSIONS............................. 33

REFERENCES................................ 34 
The objective of this study was to estimate manufacturing costs and selling prices of chromic chloride and ferrous chloride REDOX chemicals for the NASA REDOX ENERGY storage system. The results showed that the chemicals could be produced on a commodity scale for profitable sale at a cost-effective price for the REDOX system. Estimated prices for the chemicals from the two most favorable manufacturing processes corresponded to specific energy storage costs ranging from under $\$ 9$ to $\$ 11 / \mathrm{kWh}$.

The study was conducted in two parts: (1) a preliminary cost comparison of four different manufacturing processes and (2) a refined and expanded cost evaluation and cost sensitivity analysis of the most attractive process identified in the cost comparison. The cost estimates were based on grass-roots construction and operation of plants with capacities for 69000 metric tons per year of chromic chloride, anhydrous basis, and an equivalent amount of ferrous chloride, 54000 tons per year, anhydrous basis. The four proposed processes were:

- Reductive chlorination of chrome ore

- Chlorination of prereduced ore

- Electrolytic reduction of sodium chromate

- Methanol reduction of sodium chromate

The methanol process was selected as the most attractive for the refined and expanded analysis on the basis of cost, apparent technical feasibility, and commercial interest.

Projected price of REDOX chemicals for the base-case plant capacity of 69000 metric tons/year was $\$ 1.26 / \mathrm{kg}$ of chromic chloride (anhydrous basis) including ferrous chloride. The selling price ranged from $\$ 1.10 / \mathrm{kg}$ to $\$ 1.68 / \mathrm{kg}$ when the plant capacity decreased from 138000 metric tons/year to 27680 tons per year. Cost sensitivity analysis showed that a $25 \%$ change in capital cost caused only a $8.7 \%$ change in price. Price was considerably less sensitive to changes in cost of individual raw materials and fuel.

The results support the NASA REDOX system as a potentially economically feasible device for bulk storage of electrical energy. 


\section{INTRODUCTION}

The NASA REDOX Energy Storage System is intended for bulk storage of electrical energy with potential applications for utility load-leveling and storage for solar photovoltaic and wind energy facilities. The advantages of the REDOX system over other advanced battery concepts derive from the simplicity of its design and electrochemical operation. It is a flowing electrolyte battery in which both electrode redox couples are fully dissolved in aqueous solutions at all states of charge. The solutions are stored outside the power cell stack in tanks and circulated through the cell during charging and discharging operations. The negative electrode couple, chromous/chromic $\left(\mathrm{Cr}^{+2} / \mathrm{Cr}^{+3}\right)$, and the positive electrode couple, ferric/ferrous $\left(\mathrm{Fe}^{+3} / \mathrm{Fe}^{+2}\right)$, are initially supplied to the system in the fully discharged state as chromic chloride and ferrous chloride in dilute hydrochloric acid solutions. These are the redox chemicals which are the subject of the present cost study.

The REDOX system, which has been under development at the NASA-Lewis Research Laboratories since 1974, is emerging as one of the more technically feasible devices for bulk storage of electrical energy among the various advanced batteries currently being developed. High roundtrip energy efficiencies have been demonstrated, e.g., $75 \%$ at 300 amperes per square meter with a 310-square centimeter cell stack. No cycle life limitations have been observed during tens of thousands of deep-discharge cycles with a 310-square centimeter single cell (Ref. 1). The device construction and assembly is based on relatively inexpensive and existing electrodialysis and fuel cell technologies (Ref. 2), it operates at near ambient temperature and pressure, and it has minimal corrosion and sealing problems and minimal environmental and safety hazards. With its basic technical problems solved, it has strong potential for relatively near-term commercialization.

The economic feasibility of the device, however, has been under serious question because of concern over the cost and availability of the chromic chloride electrode reactant. A system cost study conducted by United Technologies Corporation showed that the price of chromic chloride could have a dominant impact on the total REDOX system cost (Ref. 2). This is shown in the following cost projection taken from the UTC study for production of one hundred $10 \mathrm{MW} / 100 \mathrm{MWh}$ REDOX systems per year:

Specific Energy Storage Cost, $\$ / k W h$ When $\mathrm{CrCl}_{3} \cdot 6 \mathrm{H}_{2} \mathrm{O}$ Price is

\section{$\$ 2.86 / \mathrm{kg} \quad \$ 0.72 / \mathrm{kg}$}

Chromic Chloride Storage Cost Total System Cost
56

110
14

65 
The system would be economically unattractive with chromic chloride at the 1980 market price (the time of the UTC study) of $\$ 2.86 / \mathrm{kg}$; but at one fourth this price, for example, the system cost would be competitive with other storage technologies and attractive for utility storage.

Early in the NASA REDOX program there was good reason to believe that the price of chromic chloride could be reduced substantially by use of a more direct production route from the ore and by achieving economy of large scale operation. Chromic chloride is a low volume chemical with little commercial value. It is produced in only ton quantities annually by several specialty chemical companys by chemical reduction of chromic acid $\left(\mathrm{CrO}_{3}\right)$ in hydrochloric acid. Chromic acid, on the other hand, is produced in tens of thousands of tons annually; and even though it is made by a relatively lengthy step-wise conversion process from chromite ore, its price is a small fraction of the price of chromic chloride. The chromium value in the ore is first converted to sodium chromate which is then converted to sodium bichromate which is finally converted to chromic acid. The fact that unit costs can be reduced substantially through economy of scale is reflected in the following comparison of the annual U.S. production volumes and prices of these chrome chemicals. The price of chromic chloride, now offered at $\$ 14.32 / \mathrm{kg}$, is shown in the comparison to be 17-20 times higher than the prices of the commodity chromium chemicals from which it is produced when compared on the basis of contained chromium:

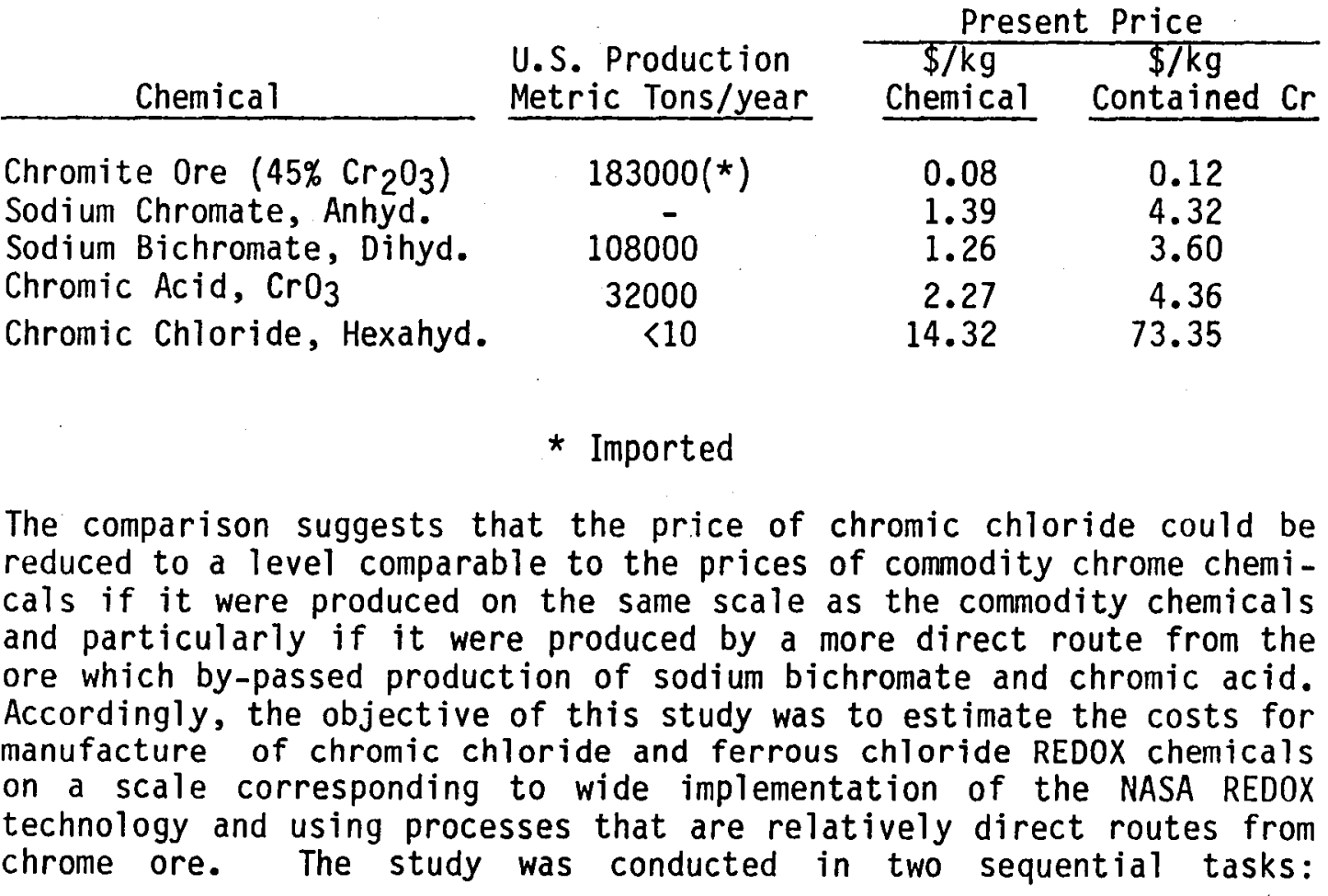


Task 1 -- A preliminary cost comparison of four proposed manufacturing processes. The comparison was based on grass-roots construction and operation of plants producing 69000 metric tons per year of chromic chloride, anhydrous basis, and an equivalent amount of ferrous chloride, 54000 metric tons per year, anhydrous basis.

Task 2 -- A refined manufacturing cost estimate of the most favorable process identified in Task 1. The refined cost estimate was then expanded from the base case plant capacity of 69000 metric tons to cost estimates for plant capacities of 27600 and 138000 metric tons per year, anhydrous basis. (These capacities correspond to 10000 , 25000 and 50000 short tons per year of contained chromium.) Also, a cost sensitivity analysis was developed for the refined base case on variation in fixed capital, raw materials, and fuel oil. Finally, a relatively detailed flow sheet was prepared with mass balances, and a list was made of the major equipment items including specifications for sizes, ratings and materials of construction.

The four proposed processes chosen for the study were the following:

- Reductive chlorination of chrome ore

- Chlorination of prereduced chrome ore

- Electrolytic reduction of sodium chromate

- Methanol reduction of sodium chromate

Although only the first three processes were specified in the contract study, the methanol process was also evaluated because of favorable laboratory results obtained at the Syracuse Research Laboratory of Allied Chemical Corporation shortly before award of this contract.

The reductive chlorination processs is the most direct route to chromic chloride from chromite ore. The process involves simultaneous reduction and chlorination of the ore at high temperature with coke and chlorine to produce vaporized chlorides of chromium, iron, aluminum and magnesium which are then isolated by selective condensation. The purified aluminum and magnesium chlorides can be sold for credit against the process costs. The basic concepts of this process were demonstrated on a laboratory scale by the U.S. Bureau of Mines in the 1930 's (Ref. 3). Yields of chromic chloride and ferric chloride were greater than $90 \%$. Pilot plant studies of essential components of the process were conducted successfully by Allied Chemical Company at the Syracuse Research Laboratory.

The chlorination of prereduced ore process is similar to the reductive chlorination process except that the coke reduction and chlorination operations are carried out separately. This process has a marked advantage over the single-step reductive chlorination process in that only chromium and iron chlorides are produced and very much smaller volumes of inert gasses are handled which, therefore, require smaller condensers. The process concept is based on results reported by the 
U.S. Bureau of Mines which showed that up to $80 \%$ of the chromium and $90 \%$ of the iron in chromite ore can be reduced to their carbides by coke at $1300^{\circ} \mathrm{C}$ (Ref. 3). Furthermore, pilot plant studies at the Syracuse Research Laboratory of Allied Chemical Company showed that ferrochrome (iron and chromium carbides) can be readily converted into vaporized chromic chloride and ferric chloride by high temperature reaction with chlorine. The aluminum and magnesium values remain as inert oxides in this process.

The electrolytic and methanol reduction processes are similar to each other in that hexavalent sodium chromate or bichromate is reduced to the trivalent state by electricity in one case and by methanol in the other case. These processes also have in common the attractive feature that a major portion utilizes existing commercial technology for conversion of chromite ore to sodium chromate liquor. The concepts of these processes were based on results of laboratory studies at the Syracuse Research Laboratory of Allied Corporation on development of new routes to trivalent chromium compounds.

Although none of the processes have been demonstrated in full detail, they are amenable to relatively accurate cost evaluation according to procedures of sound engineering practice. Details of the processes are described in the next section. 


\section{PROCESS DESCRIPTIONS}

Four proposed processes were evaluated on the basis of grass-roots construction and operation of plants with capacities to produce 69000 metric tons per year chromic chloride and an equivalent amount of ferrous chloride, 54000 metric tons per year, both anhydrous basis. Descriptions of the processes follow.

Reductive Chlorination of Chrome Ore

A flow diagram for the reductive chlorination process is shown in Figure 1. The final products are (1) anhydrous chromic chloride $\left(\mathrm{CrCl}_{3}\right)$ blended with five mole percent chromous chloride $\left(\mathrm{CrCl}_{2}\right)$ which is necessary to promote dissolution of the anhydrous product, (2) a saturated aqueous solution of ferrous chloride $\left(\mathrm{FeCl}_{2}\right)$ (about 10 molar), (3) anhydrous aluminum chloride ( $\mathrm{AlCl}_{3}$ ) and (4) hydrated magnesium chloride $\left(\mathrm{MgCl}_{2} \cdot 6 \mathrm{H}_{2} \mathrm{O}\right)$. Credit for sale of the aluminum and magnesium chlorides was assumed in the analysis.

Only 67 percent of the required amount of $\mathrm{FeCl}_{2}$ is produced from the ore; the rest is made by a single-step reaction of scrap iron with hydrochloric acid (not shown in the flow chart). Overall yields of $\mathrm{CrCl}_{3} / \mathrm{CrCl}_{2}$ from the ore is assumed to be 86 percent, and yield of $\mathrm{FeCl}_{2}$ from ore and scrap iron is assumed to be $99 \%$.

Grade B chromite ore is introduced into a set of parallel reactors operated at $950^{\circ} \mathrm{C}$ where it is chlorinated using gaseous chlorine feed, coke as the reducing agent, and air.

Coke feed is based on optimizing the $\mathrm{CO} / \mathrm{CO}_{2}$ mix in the off-gas to achieve the desired chlorination reactor temperature. The chlorination reaction is exothermic and is able to provide preheat for gas and solid feed streams and to maintain the reactors at the desired temperature.

The chlorinator off-vapors (containing the metal chlorides and $\mathrm{Cl}_{2}$, $\mathrm{CO} / \mathrm{CO}_{2}, \mathrm{~N}_{2}$ and impurities) are cooled to $600^{\circ} \mathrm{C}$ in a set of parallel brick condensers where $\mathrm{CrCl}_{3}$ and $\mathrm{MgCl}_{2}$ are removed as solids.

The $\mathrm{CrCl}_{3}$ and $\mathrm{MgCl}_{2}$ solids are further cooled to room temperature and the mixture is leached with water. The leached product is filtered and the solution containing $\mathrm{MgCl}_{2}$ is evaporated whereby pure $\mathrm{MgCl}_{2} \cdot 6 \mathrm{H}_{2} \mathrm{O}$ is obtained.

The $\mathrm{CrCl}_{3}$ remaining in the filter cake is purified by means of a resublimation process at $950^{\circ} \mathrm{C}$ and a condensation step where pure $\mathrm{CrCl}_{3}$ is obtained. Because anhydrous $\mathrm{CrCl}_{3}$ is difficultly soluble in water, it is necessary to add to the $\mathrm{CrCl}_{3}$ small amounts of $\mathrm{CrCl}_{2}$. The mixture $\mathrm{CrCl}_{3} / \mathrm{CrCl}_{2}$ is readily soluble in water. 


\section{FIGURE 1}

PROCESS SCHEME FOR REDUCTIVE CHLORINATION OF CHROME ORE

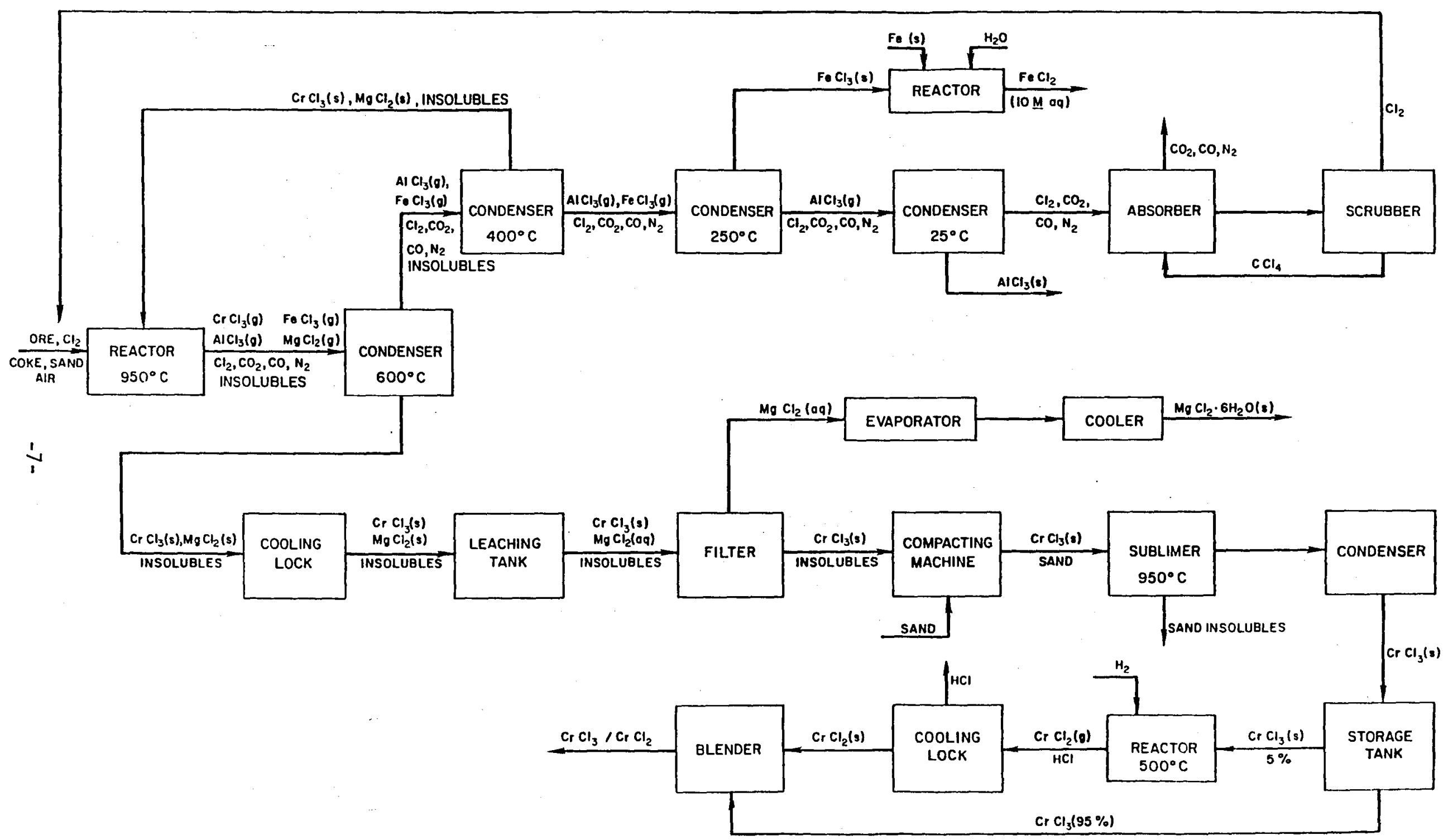


$\mathrm{CrCl}_{2}$ is prepared by reducing $\mathrm{CrCl}_{3}$ with hydrogen at $500^{\circ} \mathrm{C}$. Five percent of the $\mathrm{CrCl}_{3}$ obtained from the condenser is introduced into a hydrogenation reactor where it is converted to $\mathrm{CrCl}_{2}$. The hydrogen chloride by-product from the reduction reaction is cooled and scrubbed to produce concentrated acid.

The $\mathrm{CrCl}_{2}$ is then blended with the $\mathrm{CrCl}_{3}$ and the mixture sealed in air tight containers (to prevent aerial oxidation of $\mathrm{CrCl}_{2}$ ) for shipment to the site of the REDOX Storage System where it is dissolved in dilute hydrochloric acid.

The exhaust vapors of ferric chloride $\left(\mathrm{FeCl}_{3}\right), \mathrm{AlCl}_{3}, \mathrm{Cl}_{2}, \mathrm{CO} / \mathrm{CO}_{2}$ and $\mathrm{N}_{2}$ from the $\mathrm{CrCl}_{3} / \mathrm{MgCl}_{2}$ condensers are subjected to fractional condensation steps as follows:

A second condenser, which reduces the temperature of the gases from $600^{\circ} \mathrm{C}$ to $400^{\circ} \mathrm{C}$, recovers the uncondensed $\mathrm{CrCl}_{3}, \mathrm{MgCl}_{2}$ and insolubles. These products are recycled to the chlorination reactors. The off gases from this second condenser are withdrawn to a $\mathrm{FeCl}_{3}$ condenser where they are cooled from $400^{\circ} \mathrm{C}$ to $250^{\circ} \mathrm{C}$ at which temperature pure solid $\mathrm{FeCl}_{3}$ is obtained.

The $\mathrm{FeCl}_{3}$ is converted to $\mathrm{FeCl}_{2}$ by reaction with metallic iron in an aqueous solution. Sufficient water is added to yield a saturated solution (about 10 molar) of $\mathrm{FeCl}_{2}$. The $\mathrm{FeCl}_{2}$ is stored in sealed containers, protected from aerial oxidation, for shipment to the site of the REDOX Storage System.

The remaining vapor from the $\mathrm{FeCl}_{3}$ condenser is introduced into an $\mathrm{AlCl}_{3}$ condenser where pure $\mathrm{AlCl}_{3}$ is obtained.

The exhausted gases from the $\mathrm{AlCl}_{3}$ condenser are sent to a chlorine recovery system consisting of a carbon tetrachloride adsorption/ stripper unit. The $\mathrm{Cl}_{2}$ stripped from the system is returned to the main chlorination reactors.

Chlorination of Prereduced Chrome Ore

A flow diagram of the process for chlorination of prereduced chrome ore is shown in Figure 2. Final products of this process are (1) anhydrous chromic chloride blended with five mole percent chromous chloride to promote dissolution and (2) a saturated aqueous solution of ferrous chloride (about $10 \mathrm{molar}$ ). As in the reductive chlorination process, 33 percent of the ferrous chloride is made by reaction of hydrochloric acid with scrap iron (not shown); the rest of the ferrous chloride is derived from the chrome ore. 


\section{PROCESS SCHEME FOR CHLORINATION OF PREREDUCED CHROME ORE}

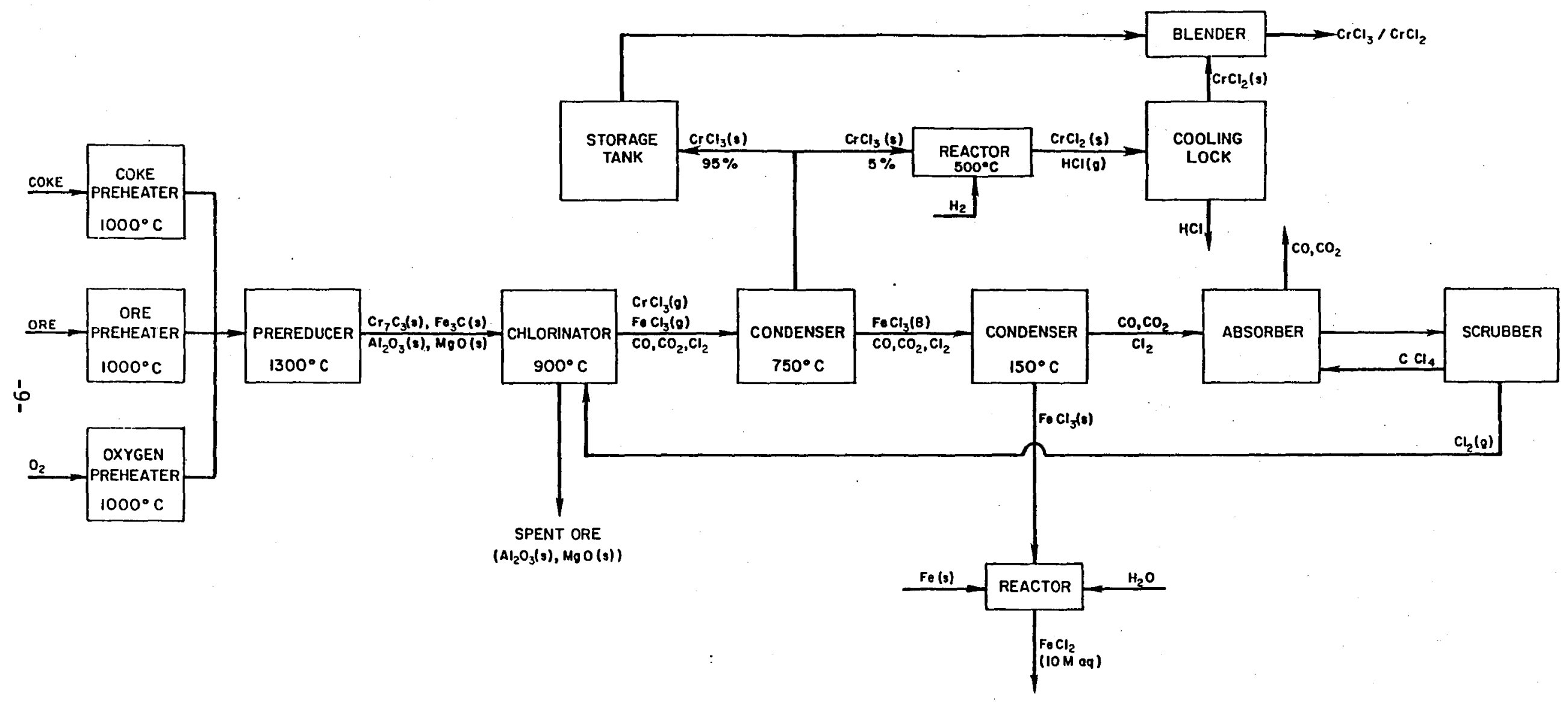


Overall yield of $\mathrm{CrCl}_{3} / \mathrm{CrCl}_{2}$ is assumed to be 86 percent and of $\mathrm{FeCl}_{2}$ from ore and scrap iron is assumed to be 99 percent.

Grade B chromite ore, coke, and oxygen are preheated before they are introduced into the reducing reactors since the prereduction reaction of chromite ore is strongly endothermic. The temperature in the reducing kiln is maintained at $1300^{\circ} \mathrm{C}$ to insure rapid conversion of the chromium and iron oxides to the corresponding carbides. Other products include the oxides of magnesium and aluminum as well as the off vapors, $\mathrm{CO}$ and $\mathrm{CO}_{2}$.

Solids from the prereducing $\mathrm{kiln}$ are fed together with $\mathrm{Cl}_{2}$ into a chlorinator. The chlorination reaction is exothermic and maintains the reactor at $900^{\circ} \mathrm{C}$. The magnesium and aluminum oxides remain inert throughout the chlorination process and are removed as spent ore. The chlorination off-vapors, $\mathrm{FeCl}_{3}, \mathrm{CrCl}_{3}, \mathrm{CO}, \mathrm{CO}_{2}, \mathrm{Cl}_{2}$, are cooled to $750^{\circ} \mathrm{C}$ in a set of brick condensers where $\mathrm{CrCl}_{3}$ selectively condenses as a solid.

Small amounts of $\mathrm{CrCl}_{2}$ must be added to anyhydrous $\mathrm{CrCl}_{3}$ in order to promote solubility in water. Chromous chloride is produced by reducing $\mathrm{CrCl}_{3}$ with hydrogen gas at $500^{\circ} \mathrm{C}$. Five percent of the condensed $\mathrm{CrCl}_{3}$ is introduced into a hydrogenation reactor where it is reduced to $\mathrm{CrCl}_{2}$. The products, $\mathrm{CrCl}_{2}$ and $\mathrm{HCl}$, are passed to a cooling lock where $\mathrm{CrCl}_{2}$ is isolated as a solid. The $\mathrm{HCl}$ is cooled and scrubbed to produce concentrated acid.

The $\mathrm{CrCl}_{2}$ and $\mathrm{CrCl}_{3}$ are then combined and the mixture is sealed in air tight containers to prevent aerial oxidation of $\mathrm{CrCl}_{2}$. This mixture can be dissolved in dilute hydrochloric acid after shipment to the site of the REDOX Storage System.

The exhaust vapors from the $\mathrm{CrCl}_{3}$ condenser, $\mathrm{FeCl}_{3}, \mathrm{CO}, \mathrm{CO}_{2} \mathrm{Cl}_{2}$, are passed into a condenser cooled to $150^{\circ} \mathrm{C}$ where $\mathrm{FeCl}_{3}$ solidifies. Offgases from the $\mathrm{FeCl}_{3}$ condenser, $\mathrm{CO}, \mathrm{CO}_{2}, \mathrm{Cl}_{2}$, are passed to a chlorine recovery system. The $\mathrm{Cl}_{2}$ stripped from the system is returned to the chlorination reactors.

The ferrous chloride is converted from $\mathrm{FeCl}_{3}$ by reduction with metallic iron in aqueous solution. Sufficient water is added to produce a saturated solution (5 molar) of $\mathrm{FeCl}_{2}$. The $\mathrm{FeCl}_{2}$ is shipped to the REDOX Storage System in sealed containers protected against air oxidation. 
Electrolytic Reduction of Sodium Chromate

The flow diagram for this process is shown in Figure 3 . The front end of the process, sodium chromate production, utilizes present commercial manufacturing technology for chrome chemicals. Yield of chromium value is assumed to be 85 percent for sodium chromate production and with additional small losses in the rest of the process, 82 percent overall.

Grade B chrome ore is crushed, dried, and ground in ball mills to a fineness of 90-98 percent through 200 mesh. The pulverized ore is then mixed with soda ash and a diluent consisting of dried ground ore residue from previous operation.

After thorough blending, the mixture is roasted in oil-fired rotary kilns in which an oxidizing atmosphere is maintained. Temperature in the firing zone is closely controlled at $1100-1150^{\circ} \mathrm{C}$. Time for passage of the material through the kiln is of the order of four hours.

The product from the kiln passes through a rotary cooler where it is cooled and the air used for combustion in the kiln is preheated. The cooled product then is leached to dissolve the sodium chromate in false-bottomed boxes called filters. Liquid is pumped onto the top of the charge, percolates downward, and is drawn off as a clear solution at the bottom. A battery of filters is arranged for countercurrent leaching, and a nearly saturated solution is obtained.

Part of the residue from leaching is dried, ground to pass 100 mesh, and is recycled as a diluent in the original mix, as described above. The remainder is discarded.

Sodium chromate in the yellow liquor is reduced to trivalent sodium chromite $\left(\mathrm{NaCr}(\mathrm{OH})_{4}\right)$, and sodium hydroxide $(\mathrm{NaOH})$ by cathodic reduction in electrolytic cells. The oxidation product, $\mathrm{O}_{2}$, at the anode is discharged to the atmosphere. Current efficiency for the cathode reaction is assumed to be 60 percent at a cell voltage of $3.5 \mathrm{~V}$ and current density of $2000 \mathrm{~A} / \mathrm{m}^{2}$. 
FIGURE 3

PROCESS SCHEME FOR ELECTROLYTIC REDUCTION OF SODIUM CHROMATE

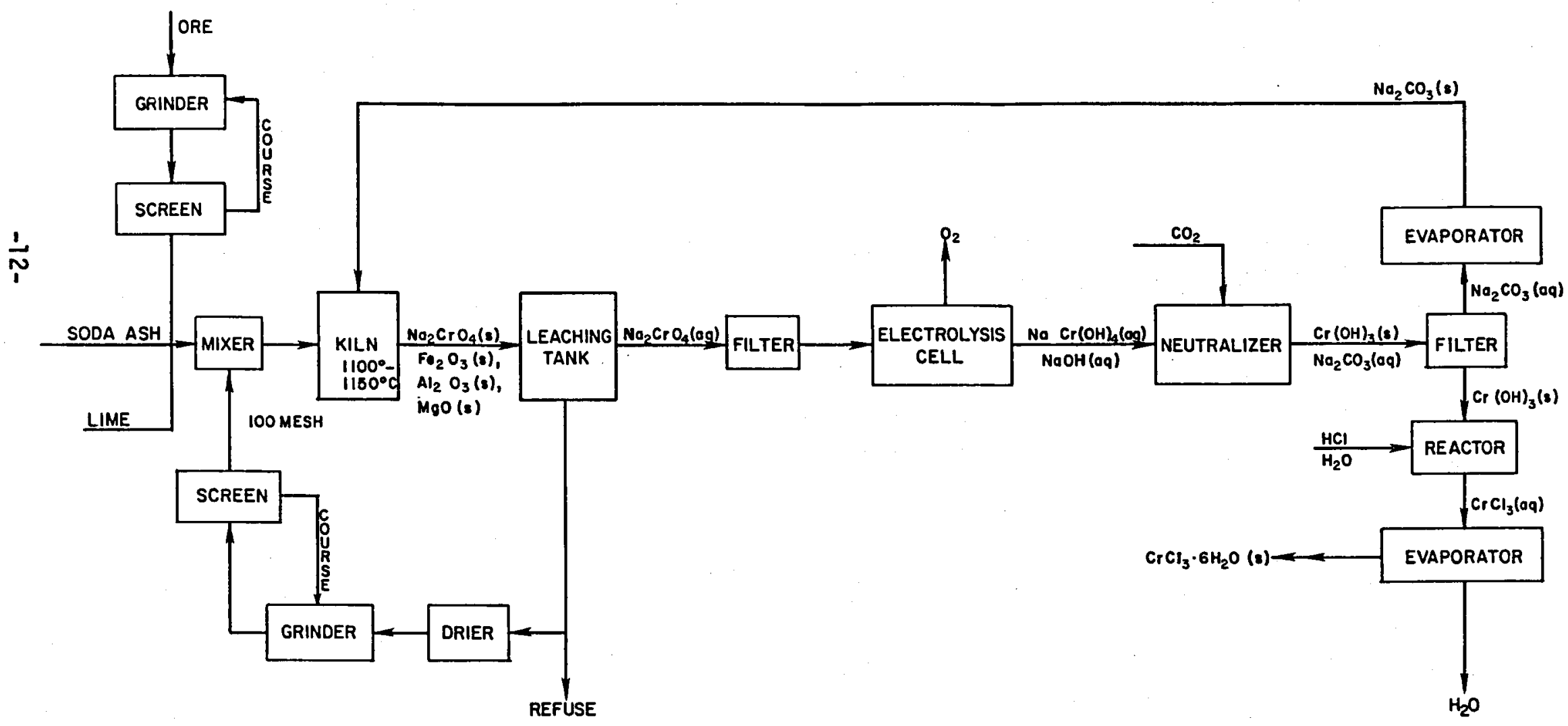


Isolation of trivalent chromium from the sodium ions is accomplished by neutralization and filtration operations. Carbon dioxide is added to the $\mathrm{NaCr}(\mathrm{OH})_{4} / \mathrm{NaOH}$ catholyte to decrease the basicity of the solution and cause hydrous chromic hydroxide $\left(\mathrm{Cr}(\mathrm{OH})_{3}\right)$ to precipitate. The soluble product, sodium carbonate $\left(\mathrm{Na}_{2} \mathrm{CO}_{3}\right)$, contains all the sodium ions. Filtration separates solid $\mathrm{Cr}(\mathrm{OH})_{3}$ from the $\mathrm{Na}_{2} \mathrm{CO}_{3}$ solutions.

Water is stripped from the $\mathrm{Na}_{2} \mathrm{CO}_{3}$ solution and the solid soda ash is recycled to the ore roasting operation.

The solid $\mathrm{Cr}(\mathrm{OH})_{3}$ from the filtration step is converted to a 2 molar solution of $\mathrm{CrCl}_{3}$ by reaction with $\mathrm{HCl}$ and $\mathrm{H}_{2} \mathrm{O}$ in a reactor. Evaporation of the solution yields the solid product $\mathrm{CrCl}_{3} .6 \mathrm{H}_{2} \mathrm{O}$ which is packaged for shipping.

Ferrous chloride is produced separately as a saturated solution (about five molar) by a single-step reaction of scrap iron with hydrochloric acid (not shown).

Methanol Reduction of Sodium Chromate

The flow diagram for this process is shown in Figure 4. As with the electrolytic process, the section for production of sodium chromate yellow liquor utilizes present commercial manufacturing technology for chrome chemicals. Yield of chromium value is assumed to be 85 percent for sodium chromate production and $82 \%$ overall.

Production of sodium chromate yellow liquor was described previously for the electrolytic reduction process. In a single reduction operation, the yellow liquor is acidified with hydrochloric acid and the resultant sodium bichromate is reduced to $\mathrm{CrCl}_{3}$ with excess methanol. The $\mathrm{CO}_{2}$ by-product is discharged to the atmosphere. The reduced solution is cooled, the sodium chloride product crystallized out and separated by filtration.

Chromic chloride hexahydrate is isolated by evaporation and crystallization.

Excess methanol is recovered from $\mathrm{CrCl}_{3}$ evaporator, purified by distillation, and recycled to the chromate reduction reaction.

Ferrous chloride is produced separately as a saturated solution (about 5 molar) by a single-step reaction of scrap iron with hydrochloric acid (not shown). Yield is assumed to be 99 percent. 
FIGURE 4

PROCESS SCHEME FOR METHANOL REDUCTION OF SODIUM CHROMATE

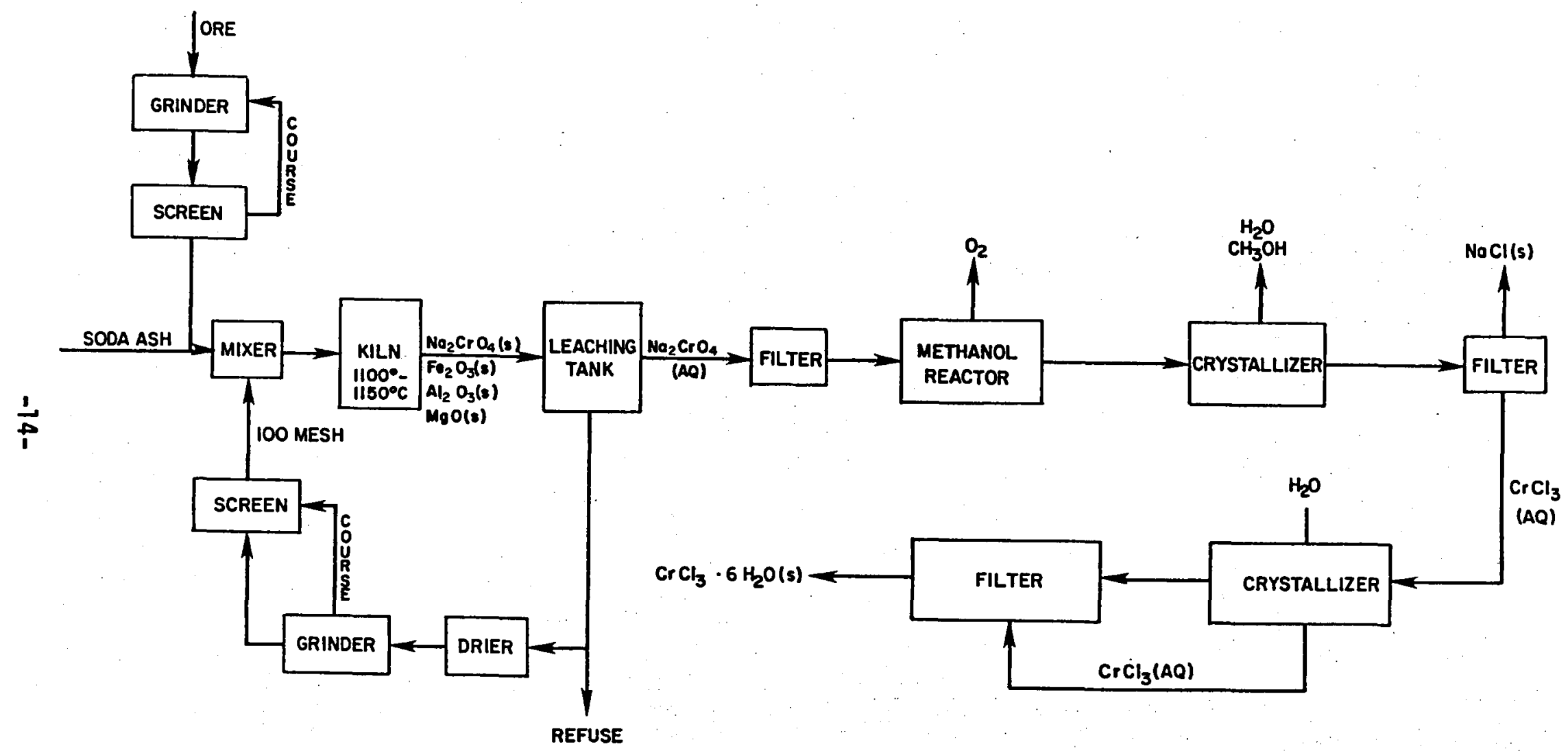


RESULTS AND DISCUSSION OF TASK 1

PRELIMINARY COST COMPARISON

\section{Task 1 Cost Summary}

Two of the processes were projected to yield selling prices of REDOX chemicals equal to or below the NASA objective of $\$ 1.19 / \mathrm{kg}$ anhydrous chromic chloride. Chlorination of prereduced chrome ore and methanol reduction of sodium chromate were projected to be the lowest cost processes yielding estimated selling prices of, respectively, $\$ 0.99$ and $\$ 1.23 / \mathrm{kg}$ anhydrous chromic chloride. It should be noted that these prices include an equivalent quantity of co-product ferrous chloride, whereas the NASA objective was for chromic chloride alone.

Estimated selling prices of REDOX chemicals from the four processes ranged from $\$ 0.99$ to $\$ 1.91 / \mathrm{kg}$ anhydrous chromic chloride as shown in Table I.

TABLE I

ESTIMATED SELLING PRICE OF

CHROMIC CHLORIDE AND FERROUS CHLORIDE

(LAST HALF 1981 DOLLARS)

(30\% ROI, FOB PLANT)

\begin{tabular}{lc}
\hline Manufacturing Process & $\begin{array}{c}\text { \$/kg Anhydrous } \mathrm{CrCl}_{3}, \\
\text { Including } \mathrm{FeCl}_{2}\end{array}$ \\
\hline $\begin{array}{l}\text { Chlorination of Prereduced } \\
\text { Chrome Ore }\end{array}$ & 0.99 \\
$\begin{array}{l}\text { Methanol Reduction of } \\
\text { Sodium Chromate }\end{array}$ & 1.23 \\
$\begin{array}{l}\text { Electrolytic Reduction } \\
\text { of Sodium Chromate } \\
\begin{array}{l}\text { Reductive Chlorination } \\
\text { of Chrome Ore }\end{array}\end{array}$ \\
\hline
\end{tabular}


Projected energy storage costs corresponding to the price estimates at $30 \%$ before-tax return on investment (ROI) for chromic chloride and ferrous chloride and purchased hydrochloric acid are compared in Table II. The projections were based on the same system operating parameters and assumptions utilized in recently published cost projections for REDOX Energy Storage Systems (Ref. 2), except that the storage costs presented here correspond to initial storage capacity. They do not include make-up chemicals that would be required because of losses over years of REDOX system operation (see Study Discussion section for details). Projected energy storage costs for chemicals from the two lowest cost processes ranged from $\$ 8.48$ to $\$ 11.06 / \mathrm{kWh}$ for 500-kWh and 100-MWh REDOX batteries. These costs are considerably more attractive than the previous projections of $\$ 25$ and $\$ 22 / \mathrm{kWh}$, respectively, for the two battery sizes.

In light of the chemical price estimates for the two lowest cost processes in this study, total manufacturer's selling price for RED0X systems can be reduced from the earlier projections, which ranged from $\$ 63$ to $\$ 116 / \mathrm{kWh}$, depending on the assumed cost of the chemicals (Ref. 2), to $\$ 54-59 / \mathrm{kWh}$ for the $500-\mathrm{kWh}$ system and to $\$ 51-53 / \mathrm{kWh}$ for the 100-MWh system.

TABLE II

PROJECTED ENERGY STORAGE COSTS FOR

REDOX CHEMICALS, INCLUDING PURCHASED

HYDROCHLORIC ACID

(1981 DOLLARS)

\begin{tabular}{|c|c|c|}
\hline Manufacturing Process & $\begin{array}{c}\text { Energy Storage } \\
10 \mathrm{~kW} / 500 \mathrm{kWh} \\
\text { Battery }\end{array}$ & $\begin{array}{r}\text { Cost, } \$ / \mathrm{kWh} \\
10 \mathrm{MW} / 100 \mathrm{MWh} \\
\text { Battery }\end{array}$ \\
\hline $\begin{array}{l}\text { Chlorination of Prereduced } \\
\text { Chrome Ore }\end{array}$ & 8.97 & 8.48 \\
\hline $\begin{array}{l}\text { Methanol Reduction of } \\
\text { Sodium Chromate }\end{array}$ & 11.06 & 10.50 \\
\hline $\begin{array}{l}\text { Electrolytic Reduction of } \\
\text { Sodium Chromate }\end{array}$ & 13.42 & 12.77 \\
\hline $\begin{array}{l}\text { Reductive Chlorination } \\
\text { of Chrome Ore }\end{array}$ & 17.09 & 16.30 \\
\hline
\end{tabular}


A recommendation was made to NASA-Lewis REDOX program management, and accepted, that Task 2 should be undertaken to perform the refined cost study and sensitivity analysis on the methanol reduction process. This process is believed to be the best defined technically of all the processes and has the greatest probability for development to commercial success. It also may be the most desirable process from a commercial standpoint because it would allow coproduction of present commercially important chrome chemicals, and it could utilize an existing chromic acid plant where capacity is available.

\section{Discussion of Task 1 Results}

Capital requirements for the four processes are itemized in Table III, including fixed capital, working capital, and cost of technology (R\&D). Chlorination of prereduced ore and methanol reduction of sodium chromate are projected to have comparable investment requirements, $\$ 72$ million, which are considerably lower than the other two processes, $\$ 110$ million for electrolytic reduction and $\$ 275 \mathrm{million}$ for reductive chlorination. The large fixed capital requirement for the reductive chlorination process is associated with the extraordinarily large brick condensers which would occupy an area of about six acres. The condensers have to be this large in order to handle the voluminous quantities of combustion air gases and chlorine at low enough velocity so as to avoid entrainment of the metal halide condensates. In contrast, the process of chlorination of prereduced ores does not pass combustion air through the system and, consequently, the condensers would be only one twentieth as big. Besides the cost factor, the technical feasibility of condenser sections of the reductive chlorination process is questionable.

The higher capital cost for the electrolytic process is associated with the cost of the electrolysis cells. Electrolysis cells are shown to be expensive forms of reactors.

Annual operating costs and charges for the four processes are itemized in Tables IV and $V$. Reductive chlorination of chrome ore is projected to have one of the lowest net operating costs because of credits taken for sale of by-products. This is in spite of high estimated maintenance costs. The estimated selling price of REDOX chemicals from this process, however, is highest because of the very large capital requirements. The electrolytic reduction process has the highest operating costs, $\$ 71$ million, largely because of high electricity charges to operate the cells.

Energy storage costs for REDOX chemicals based on the estimated selling prices from the four processes were given earlier in Table II. The costs include purchased hydrochloric acid. 
TABLE III

CAPITAL INVESTMENT FOR MANUFACTURE OF REDOX CHEMICALS

(69000 METRIC TONS/YEAR CrCl3, 54000 METRIC TONS/YEAR FeC/2)

(ks, 1981)

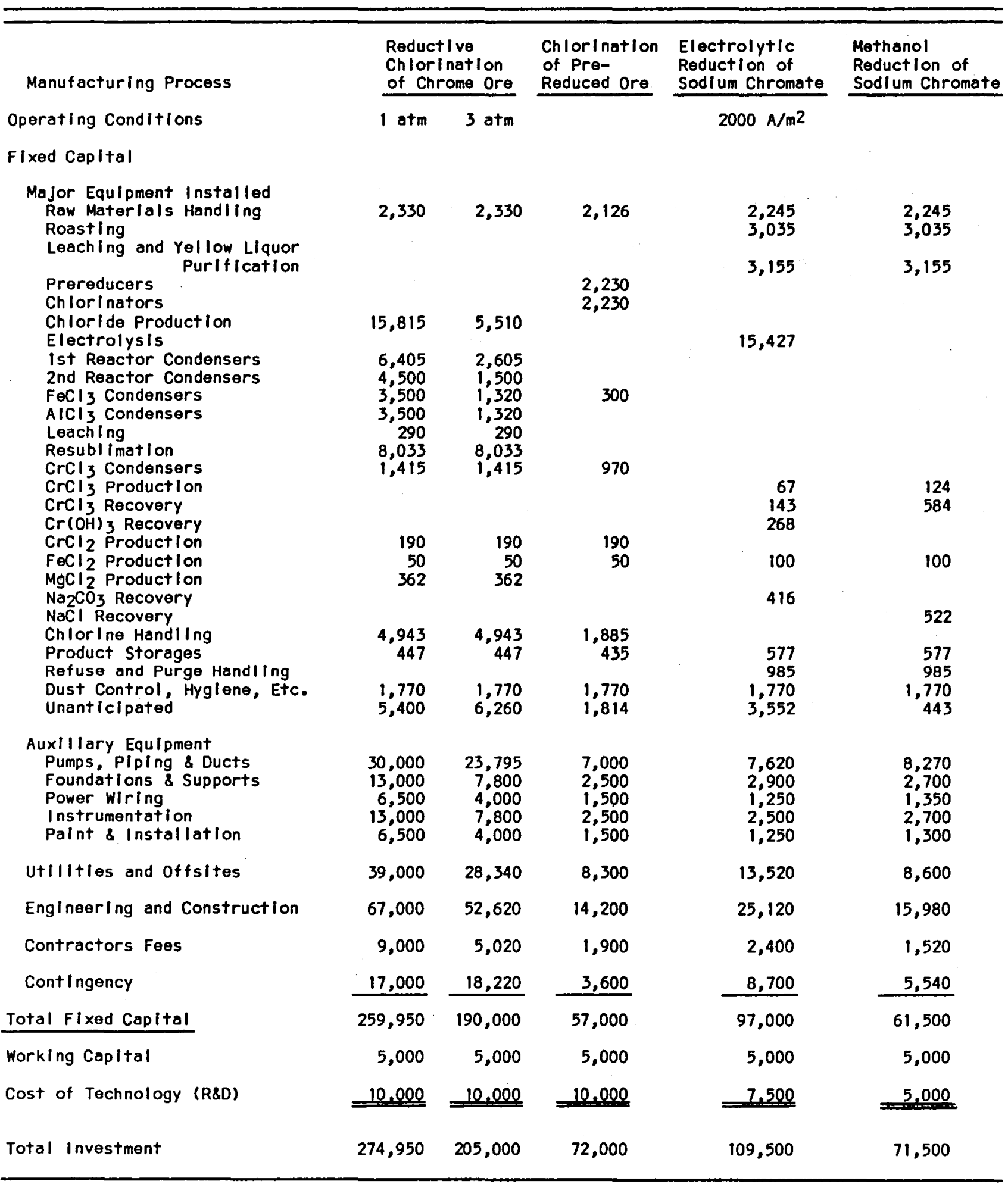


TABLE IV

ANNUAL OPERATING COSTS FOR MANUFACTURE OF REDOX CHEMICALS (69000 METRIC TONS/YEAR $\mathrm{CrCl}_{3}, 54000$ METRIC TONS/YEAR FeCI ${ }_{2}$ )

(k\$, 1981)

\begin{tabular}{|c|c|c|c|c|c|}
\hline Manufacturing Process & $\begin{array}{l}\text { Reduc } \\
\text { Chlor } \\
\text { of } \mathrm{Ch}\end{array}$ & $\begin{array}{l}\text { ve } \\
\text { at I on } \\
\text { me Ore }\end{array}$ & $\begin{array}{l}\text { Chlorinatlon } \\
\text { of Pre- } \\
\text { Reduced Ore }\end{array}$ & $\begin{array}{l}\text { El ectrolytic } \\
\text { Reduction of } \\
\text { Sodlum Chromate }\end{array}$ & $\begin{array}{l}\text { Methanol } \\
\text { Reduction of } \\
\text { Sodium Chromate }\end{array}$ \\
\hline Operating Conditions & $1 \mathrm{~atm}$ & $3 \mathrm{~atm}$ & & $2000 \mathrm{~A} / \mathrm{m}^{2}$ & \\
\hline \multicolumn{6}{|l|}{ Manuf acturing Costs } \\
\hline 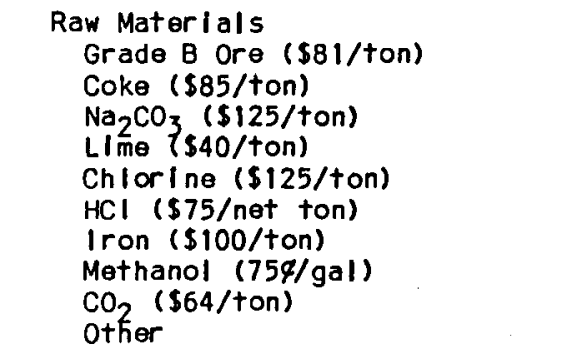 & $\begin{array}{r}7,300 \\
5,993 \\
16,550 \\
860\end{array}$ & $\begin{array}{r}16,550 \\
860 \\
500\end{array}$ & $\begin{array}{r}10,600 \\
860 \\
300\end{array}$ & $\begin{array}{r}7,830 \\
2,640 \\
600 \\
7,220 \\
2,600 \\
1,350 \\
100\end{array}$ & $\begin{array}{r}8,100 \\
8,740 \\
600 \\
9,720 \\
2,600 \\
3,600 \\
200\end{array}$ \\
\hline $\begin{array}{l}\text { Fuel and utillties } \\
\text { Electriclty }(35 \mathrm{mils}) \\
\text { Fuel oll (80\%/gal) } \\
\text { Cool Ing Water }\end{array}$ & $\begin{array}{r}1,420 \\
300\end{array}$ & $\begin{array}{r}1,420 \\
300\end{array}$ & $\begin{array}{r}1,420 \\
300\end{array}$ & $\begin{array}{r}12,120 \\
9,336\end{array}$ & $\begin{array}{l}1,800 \\
9,700\end{array}$ \\
\hline $\begin{array}{l}\text { Operating Labor ( } \$ 30 \mathrm{~K} / \mathrm{man} \text { yr) } \\
\text { Direct SupervIsI on }(20 \$ \text { of } \mathrm{OL}) \\
\text { Overheads }(40 \$ \text { of } \mathrm{OL}) \\
\text { Malntenance } \\
\text { Depreclation } \\
\text { Taxes and Insurance }\end{array}$ & $\begin{array}{r}3,900 \\
780 \\
1,900 \\
10,000 \\
26,000 \\
4,000 \\
\end{array}$ & $\begin{array}{r}3,900 \\
780 \\
1,900 \\
7,600 \\
19,000 \\
2,850 \\
\end{array}$ & $\begin{array}{r}3,900 \\
780 \\
1,900 \\
2,900 \\
5,700 \\
1,500 \\
\end{array}$ & $\begin{array}{r}3,900 \\
780 \\
1,900 \\
4,900 \\
9,700 \\
2,500 \\
\end{array}$ & $\begin{array}{r}3,000 \\
600 \\
1,500 \\
3,100 \\
6,150 \\
1,550 \\
\end{array}$ \\
\hline Total Manufacturing Cost & 79,503 & 68,953 & 44,120 & 67,476 & 60,960 \\
\hline Expense (Admin., etc) & 3,000 & 3,000 & 2,800 & 2,700 & 2,700 \\
\hline Carrying Charges, Working Capital & 500 & 500 & 500 & 500 & 500 \\
\hline $\begin{array}{l}\text { Credits (sale of byproducts) } \\
\mathrm{AlCl}_{3} \\
\mathrm{MgCl}_{2}\end{array}$ & $\begin{array}{r}28,200 \\
5,100 \\
\end{array}$ & $\begin{array}{r}28,200 \\
5,100 \\
\end{array}$ & & & \\
\hline Net Costs and Expenses & 49,703 & 39,153 & 47,420 & 70,676 & 64,160 \\
\hline
\end{tabular}


TABLE $V$

ANNUAL CHARGES FOR MANUFACTURE OF REDOX CHEMICALS, CHROMIC CHLORIDE AND FERROUS CHLORIDE (BASIS 69000 METRIC TONS/YEAR ANHYDROUS $\mathrm{CrCl}_{3}$ AND 54000 METRIC TONS/YEAR $\mathrm{FOCl}_{2}$ )

(k\$, 1981)

\begin{tabular}{|c|c|c|c|c|c|}
\hline \multirow{2}{*}{$\begin{array}{l}\text { Manufacturing Process } \\
\text { OperatIng ConditIons } \\
\text { Venture Capital Financing }\end{array}$} & \multicolumn{2}{|c|}{$\begin{array}{l}\text { Reduction } \\
\text { Chlorination } \\
\text { of Chrome Ore } \\
\end{array}$} & $\begin{array}{l}\text { ChlorInation } \\
\text { of Pre- } \\
\text { Reduced Ore } \\
\end{array}$ & \multirow{2}{*}{$\begin{array}{l}\text { Electrolytic } \\
\text { Reduction of } \\
\text { Sodlum Chromate } \\
2000 \mathrm{~A} / \mathrm{m}^{2}\end{array}$} & \multirow[t]{2}{*}{$\begin{array}{l}\text { Methanol } \\
\text { Reduct Ion of } \\
\text { Sodium Chromate } \\
\end{array}$} \\
\hline & 1 atm & $3 \mathrm{~atm}$ & & & \\
\hline Net Costs and Expense & 49,703 & 39,153 & 47,420 & 70,676 & 64,160 \\
\hline Less Carrying Charges & 500 & 500 & 500 & 500 & 500 \\
\hline 308 Pretax ROI & 82,485 & 61,500 & 21,600 & 32,900 & 21,500 \\
\hline Total Annual Charges & 131,688 & 100,153 & 68,520 & 103,076 & 85,160 \\
\hline $\begin{array}{l}\text { Selling Price } \mathrm{CrCl}_{3} / \mathrm{FeCl}_{2}, \\
\text { as } \$ / \mathrm{kg} \text { anhydrous } \mathrm{CrCl}_{3}\end{array}$ & 1.91 & 1.45 & 0.99 & 1.49 & 1.23 \\
\hline \multicolumn{6}{|l|}{ Guaranteed Return FInancling } \\
\hline Net Costs and Expense & 49,703 & 39,153 & 47,420 & 70,676 & 64,160 \\
\hline Less Depreciation & 26,000 & 19,000 & 5,700 & 9,700 & 6,150 \\
\hline Amortization (10 yrs e 10\%) & 43,900 & 32,600 & 10,900 & 17,000 & 10,850 \\
\hline Total Annual Charges & 67,603 & 52,753 & 52,620 & 77,976 & 68,860 \\
\hline $\begin{array}{l}\text { Selling Price } \mathrm{CrCl}_{3} / \mathrm{FeCl}_{2}, \\
\text { as } \$ / \mathrm{kg} \text { anhydrous } \mathrm{CrCl}_{3}\end{array}$ & 0.98 & 0.76 & 0.76 & 1.13 & 1.00 \\
\hline
\end{tabular}


Assumptions used in calculating storage costs were the same as in the United Technology Corporation cost projections (Ref. 2) except that the costs are based on initial storage capacity before diffusional cross-over losses through the membrane which are expected to occur slowly over years of REDOX system operation. Assumptions were the following:

$\begin{array}{ll}\text { Discharge potential, average: } & 0.9 \mathrm{~V} \\ \text { Depth of discharge range: } & 80 \% \\ \text { Capacity loss from cross-over: } & 0 \% \text { initially } \\ \text { REDOX solution compositions: } & \\ \text { Solar, } 10 \mathrm{~kW} / 500 \mathrm{kWh} & 1 \mathrm{molar} \mathrm{CrCl}_{3} / 2 \mathrm{molar} \mathrm{HCl} \\ & 1 \mathrm{molar} \mathrm{FeCl} 2 / 2 \mathrm{molar} \mathrm{HCl} \\ & 2 \mathrm{molar} \mathrm{CrCl} 3 / 2 \mathrm{molar} \mathrm{HCl} \\ \text { Utility, } 10 \mathrm{MW} / 100 \mathrm{MWh} & 2 \mathrm{molar} \mathrm{CrCl} 3 / 2 \mathrm{molar} \mathrm{HCl}\end{array}$

Gross/net storage capacity:

Solar, $10 \mathrm{~kW} / 500 \mathrm{kWh}$

Utility, $10 \mathrm{MW} / 100 \mathrm{MWh}$

$674 / 634 \mathrm{kWh} / \mathrm{kWh}$

$128 / 125 \mathrm{MWh} / \mathrm{MWh}$

Additional REDOX chemicals could be added to the storage system from time to time to make up for cross-over and other losses rather than being initially charged to the system. Make-up chemicals would be part of the system operating costs.

Purchase price of hydrochloric acid was the same as used in the present manufacturing cost estimates, i.e., $\$ 82.60 /$ metric ton, $100 \%$ basis. This price corresponds to energy storage costs for $\mathrm{HCl}$ of only $\$ 0.44 / \mathrm{kWh}$ and $\$ 0.21 / \mathrm{kWh}$ for the solar and utility size bateries, respectively. The United Technologies projections were more than ten times higher at $\$ 7.18$ and $\$ 3.43 / \mathrm{kWh}$, respectively.

Additionally, the United Technologies study assumed a cost for ferric chloride of $\$ 5 / \mathrm{kWh}$, whereas in the present study the cost of the iron chloride is combined with the chromic chloride cost (Tables I and II). The costs are combined because the chemicals are coproducts from two of the manufacturing processes.

The Allied Chemical Project Team recommended, and subsequently undertook, Task 2, Expanded Manufacturing Cost Estimate, for the process of methanol reduction of sodium chromate. Although this process is projected to yield the second lowest price for REDOX chemicals (chlorination of prereduced ore is lowest), the process is believed to be the best defined technically of all the processes. It has the greatest probability for development to commercial success. Most of this process, production of sodium chromate yellow liquor, would utilize established commercial production technology. The rest of the process, conversion of sodium chromate yellow liquor to chromic 
chloride, has been partially verified in the laboratory and is projected to involve only a few simple unit processes on a production scale. A relatively modest development effort is believed necessary to achieve commercialization. Full verification on a pilot scale would be the next phase of development. 
RESULTS AND DISCUSSION OF TASK 2

EXPANDED MANUFACTURING COST ESTIMATE

The objective of Task 2 was to refine and expand the manufacturing cost estimate of the process for methanol reduction of sodium chromate.

The refined estimate was expanded from the base case plant capacity of 69000 metric tons per year to include plant capacities of 27000 and 138000 metric tons per year of chromic chloride, anhydrous basis. A cost sensitivity analysis was then developed for the refined base case on variation in fixed capital, raw materials, and fuel oil. Finally, a flow sheet was prepared with mass balances, and a list was made of the major equipment items including specifications for sizes, ratings and materials of construction.

Results of the refined estimate of fixed capital, expanded to include the three plant capacities, were the following:

Plant Capacity

Metric Tons/year $\mathrm{CrCl}_{3}$
Price of Chromic Chloride and

Ferrous Chloride Expressed as $\$ / \mathrm{kg} \mathrm{CrCl} 3$

$\begin{array}{rr}27000 & 1.68 \\ 69000 & 1.26 \\ 138000 & 1.10\end{array}$

The results substantiate the attractive price estimate obtained in the prel iminary comparison. The small increase in price for the base-case capacity to $\$ 1.26 / \mathrm{kg}$ from $\$ 1.23 / \mathrm{kg}$ estimated in the preliminary comparison owes mainly to capital for a distillation unit for methanol recovery which was not included in the original analysis.

Results of the cost sensitivity analysis are shown in Table VI. A 25 percent increase in cost of fixed capital, raw materials and fuel oil would have a combined impact of increasing the selling price by 21 percent to $\$ 1.53 / \mathrm{kg}$. Effects of increasing costs of individual raw materials and fuel oil are minor. Selling price is particularly insensitive to the cost of methanol. A 25 percent increase in cost of methanol increases the selling price by only $0.01 \$ / \mathrm{kg}$. 
TABLE VI

Effect of 25 Percent Increase in Cost Element on Selling Price of Chromic Chloride and Ferrous Chloride (From Base-Case Selling Price of $\$ 1.26 / \mathrm{kg} \mathrm{CrCl} 3$ )

\begin{tabular}{lcc}
\hline & $\begin{array}{l}\text { Seling Price of Chromic Chloride } \\
\text { and Ferrous Chloride, Expressed } \\
\text { as } \$ / \mathrm{kg} \mathrm{CrCl}_{3}\end{array}$ & $\begin{array}{c}\text { Percent Increase } \\
\text { in Sel1ing Price }\end{array}$ \\
\hline Fost Element & 1.37 & 8.73 \\
Raw Materials & & \\
Grade B Ore & 1.29 & 2.32 \\
Soda Ash & 1.29 & 2.51 \\
Methanol & 1.27 & 0.54 \\
Hydrogen Chloride & 1.30 & 2.79 \\
Iron & 1.27 & 0.75 \\
Fuel 0il & 1.30 & 3.17 \\
Combined Effect & 1.52 & 20.81 \\
\hline
\end{tabular}


Sensitivity of selling price to variations in item costs can be expressed as a linear relationship:

$$
\begin{aligned}
& \text { Selling price }(\$ / \mathrm{kg})=1.26+S \times(\% \text { change in item cost }) \text {, } \\
& \text { where } S=0.00451 \$ / \mathrm{kg} \cdot \% \text { for fixed capital cost } \\
& =0.00461 \$ / \mathrm{kg} \cdot \% \text { for total raw materials } \\
& =0.00167 \$ / \mathrm{kg} \cdot \% \text { for fuel oil }
\end{aligned}
$$

For example, a 25 percent increase in fixed capital would require a selling price increase to $\$ 1.37 / \mathrm{kg}$ in order to maintain the same rate of return and other capital related charges calculated as follows:

$$
\begin{aligned}
\text { Selling price } & =1.26+0.00451 \times 25 \\
& =\$ 1.37 / \mathrm{kg}
\end{aligned}
$$

Annual operating charges and derived selling prices for the three plant capacities are given in Table VII.

Total Fixed Capital and investment for the three plant sizes are given in Table VIII.

Installed costs for the major capital equipment items are summarized in Table IX. The listing is the result of costing over 150 individual equipment items for each plant size.

The complete flow sheet with mass balances for the base case 69000 metric ton/year plant is given in Figure 5 .

Finally, a listing of the major equipment items and their descriptions and specifications is given in Table $x$. 


\section{TABLE VII}

Price and Annual Charges for Manufacture of Redox Chemicals Chromic Chloride and Ferrous Chloride by Methanol Reduction of Sodium Chromate for Three Plant Capacities

$(k \$, 1981)$

\begin{tabular}{|c|c|c|c|}
\hline $\begin{array}{l}\text { Plant Capacity } \\
\text { (Metric tons } \mathrm{CrCl}_{3} / \mathrm{yr} . \text { ) }\end{array}$ & $\underline{27,600}$ & $\underline{69,000}$ & $\underline{138,000}$ \\
\hline Fixed Capital (FC) & 40,700 & 65,500 & 95,400 \\
\hline \multicolumn{4}{|l|}{ Manufacturing Costs } \\
\hline $\begin{array}{l}\text { Raw Materials } \\
\text { Grade B Ore (\$81/ton) } \\
\text { Na2C03 ( } \$ 125 / \text { ton) } \\
\text { Lime }(\$ 40 / \text { ton) } \\
\text { Methanol (75f/gal) } \\
\text { HCl }(\$ 75 / \text { ton) } \\
\text { Iron }(\$ 100 / \text { ton }) \\
\text { Other }\end{array}$ & $\begin{array}{r}3,240 \\
3,500 \\
250 \\
750 \\
3,900 \\
1,040 \\
100\end{array}$ & $\begin{array}{r}8,100 \\
8,740 \\
600 \\
1,870 \\
9,720 \\
2,600 \\
200\end{array}$ & $\begin{array}{r}16,200 \\
17,480 \\
1,200 \\
3,740 \\
19,440 \\
5,200 \\
400\end{array}$ \\
\hline \multicolumn{4}{|l|}{ Fuel and Utilities } \\
\hline $\begin{array}{l}\text { Electricity }(\$ 0.035 / \mathrm{kWh}) \\
\text { Fuel 0il }(80 \% / \mathrm{gal} .)\end{array}$ & $\begin{array}{r}720 \\
4,600\end{array}$ & $\begin{array}{r}1,800 \\
11,500\end{array}$ & $\begin{array}{r}3,600 \\
23,000\end{array}$ \\
\hline $\begin{array}{l}\text { Operating Labor (OL) ( } \$ 30 \mathrm{k} / \mathrm{man} \text { yr) } \\
\text { Direct Supervision ( } 20 \% \text { of } \mathrm{OL}) \\
\text { Overheads ( } 40 \% \text { of } 0 \mathrm{~L}) \\
\text { Maintenance (5\% of FC) } \\
\text { Depreciation (10\% of FC) } \\
\text { Taxes and Insurance }(2.5 \% \text { of } \mathrm{FC})\end{array}$ & $\begin{array}{r}2,700 \\
540 \\
1,350 \\
2,040 \\
4,070 \\
1,020 \\
\end{array}$ & $\begin{array}{r}3,000 \\
600 \\
1,500 \\
3,300 \\
6,600 \\
1,650 \\
\end{array}$ & $\begin{array}{r}4,800 \\
960 \\
2,300 \\
4,770 \\
9,540 \\
2,390 \\
\end{array}$ \\
\hline Total Manufacturing Cost & 29,820 & 61,780 & 115,020 \\
\hline Expense (Admin. etc.) & 2,000 & 2,700 & 3,500 \\
\hline Return on Investment $(30 \%)$ & 14,610 & 22,650 & 33,120 \\
\hline Total Annual Charges & 46,430 & 87,130 & 151,640 \\
\hline $\begin{aligned} \text { Selling Price } & \left(\begin{array}{c}\$ / \mathrm{kg} \mathrm{CrCl} \\
\text { inc. }\end{array} \mathrm{FeCl}_{2}\right)\end{aligned}$ & 1.68 & 1.26 & 1.10 \\
\hline
\end{tabular}


TABLE VIII

Fixed Capital and Total Investment for Three Plant Sizes Producing Redox Chemicals by Methanol Reduction

of Sodium Chromate

$(k \$, 1981)$

\begin{tabular}{|c|c|c|c|}
\hline $\begin{array}{r}\text { Plant Capacity (Metric tons, } \\
\left.\qquad \mathrm{CrCl}_{3} / \mathrm{yr} .\right)\end{array}$ & $\underline{27,600}$ & $\underline{69,000}$ & $\underline{138,000}$ \\
\hline \multicolumn{4}{|l|}{ Fixed Capital } \\
\hline Major Equipment & 8,850 & 14,300 & 20,800 \\
\hline $\begin{array}{l}\text { Auxiliary Equipment } \\
\text { Piping, Chutes, Ducts } \\
\text { Foundations, Supports } \\
\text { Power Wiring } \\
\text { Instruments, Controls } \\
\text { Insulation, Paint }\end{array}$ & $\begin{array}{r}5,300 \\
1,800 \\
900 \\
1,800 \\
900 \\
\end{array}$ & $\begin{array}{l}8,600 \\
2,850 \\
1,450 \\
2,850 \\
1,450 \\
\end{array}$ & $\begin{array}{r}12,500 \\
4,200 \\
2,100 \\
4,200 \\
2,100 \\
\end{array}$ \\
\hline Total Direct Equipment & 19,550 & 31,500 & 45,900 \\
\hline Utilities and Offsites & 5,900 & 9,450 & 13,800 \\
\hline $\begin{array}{l}\text { Engineering and Construction } \\
\text { Contractor Fees }\end{array}$ & $\begin{array}{r}10,200 \\
1,500\end{array}$ & $\begin{array}{r}16,400 \\
2,100\end{array}$ & $\begin{array}{r}23,900 \\
3,100\end{array}$ \\
\hline Cont ingency & 3,750 & 5,950 & 8,700 \\
\hline Total Fixed Capital & 40,700 & 65,500 & 95,400 \\
\hline Working Capital & 3,000 & 5,000 & 10,000 \\
\hline Cost of Technology & 5,000 & 5,000 & 5,000 \\
\hline Total Investment & 40,700 & 75,500 & 110,400 \\
\hline
\end{tabular}


TABLE IX

Major Capital Equipment Installed

(Summary of 150 item costs for each plant capacity)

(1981 \$)

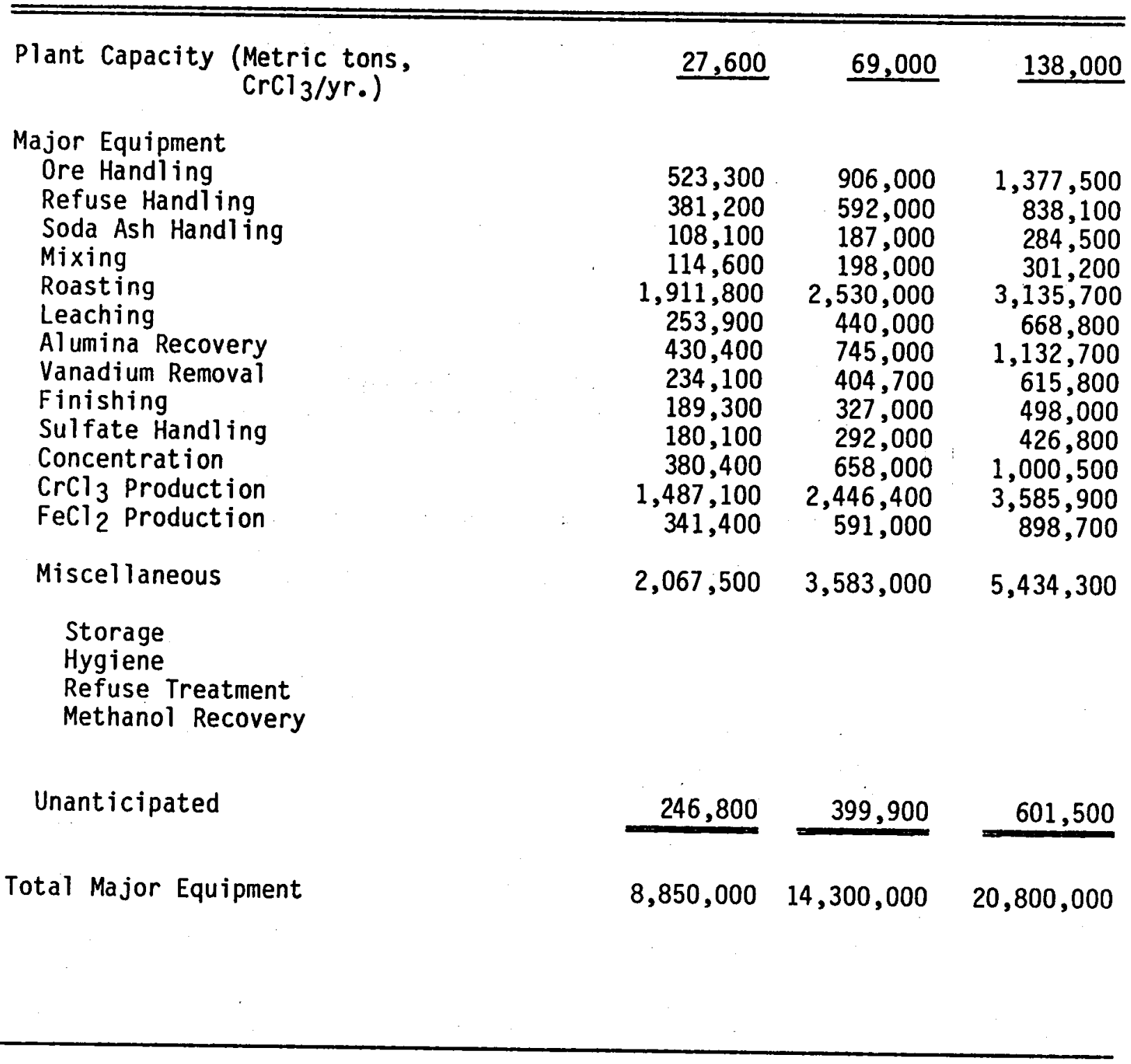


TABLE $X$

MAJOR EQUIPMENT ITEMS FOR PLANT PRODUCING

69000 METRIC TONS PER YEAR $\mathrm{CrCl}_{3}$ (ANHYDROUS BASIS)

BY METHANOL REDUCTION OF SODIUM CHROMATE

Equipment

Ore Mill System

Refuse Mill System

Rotary Kiln System

Leach Filters

Alumina Crystallizers

Alumina Thickener

Alumina Filter

Vanadate Reactors

Vanadate Thickener
Description and Specifications

Williams Super Giant Roller Mill, complete with cyclone and bag dust collectors.

William Champion Roller Mill, complete with cyclone and bag dust collectors.

$13^{\prime}$ diameter $\times 300^{\prime}$ long rotary kiln lined with A.P. Green DV-38 brick, complete with gas burner, drive, controls, exhaust gas and inlet air blowers, etc.

Dorr-0liver belt filter, complete with filtrate receivers and pumps, and vacuum pump, plus polish filters.

Three 30000-gallon vertical steel tanks with $30 \mathrm{HP}$ agitators and $200 \mathrm{ft}^{2}$ steam coils.

Rake-type thickener, $38 \mathrm{ft}$ dia $x$ $10 \mathrm{ft}$ deep, steel.

Rotary vacuum filter, $6 \mathrm{ft}$ dia $x$ $14 \mathrm{ft}$ wide, steel, complete with filtrate receivers, filtrate pumps and vacuum pumps.

6500 gallon vertical steel tank, 10 HP agitator.

Rake-type thickener, $40 \mathrm{ft}$ dia $x$ $10 \mathrm{ft}$ deep, steel. 
TABLE $X$

(Cont inued)

MAJOR EQUIPMENT ITEMS FOR PLANT PRODUCING

69000 METRIC TONS PER YEAR $\mathrm{CrCl}_{3}$ (ANHYDROUS BASIS)

BY METHANOL REDUCTION OF SODIUM CHROMATE

Equipment

Vanadate Filter

Chromate Evaporator System

Treating Tanks

Sulfate Thickeners

Sulfate Centrifuges

Chromic Chloride Reactors

Sodium Chloride Crystallizers
Description and Specifications

Rotary vacuum filter, $5 \mathrm{ft}$ dia $x$ $8 \mathrm{ft}$ wide, steel, complete with filtrate receiver, filtrate pump and vacuum pump.

Quadruple effect evaporator train, oslo crystallizing type, steel, complete with vaporizers, suspension tanks, heater, circulating pumps, liquor transfer pumps, salt legs, water pumps, barometric condenser and ejector, condensate and flash tanks, hot well, etc.

Two 5000 gallon vertical steel tanks with $45^{\circ}$ cone bottoms and $5 \mathrm{HP}$ agitators.

Two 2000 gallon steel, cone-bottom tanks with 6" variable-speed vertical screw dischargers with $5 \mathrm{HP}$ drives.

Two TerMeer centrifugal separators, steel, with $20 \mathrm{HP}$ drives.

Two 7000 gallon, rubber- 1 ined steel tanks, with internal heating coil and 12 HP agitator.

Two 7000 gallon, rubber-l ined steel tanks, with internal cooling coil and 12 HP agitator. 
TABLE $X$

(Cont inued)

MAJOR EQUIPMENT ITEMS FOR PLANT PRODUCING

69000 METRIC TONS PER YEAR $\mathrm{CrCl}_{3}$ (ANHYDROUS BASIS)

BY METHANOL REDUCTION OF SODIUM CHROMATE

Equipment

Sodium Chloride Filter

Chromic Chioride

Evaporative System

Methanol Recovery

Chromic Chloride Filter
Description and Specifications

Rotary vacuum filter, $4 \mathrm{ft}$ dia $x$ $8 \mathrm{ft}$ wide, rubber lined steel, complete with filtrate receivers, filtrate pumps and vacuum pumps.

Quadruple effect evaporator train, Oslo crystallizing type, monel clad steel, complete with vaporizers, suspension tanks, heaters, circulating pumps, liquor transfer pumps, salt legs, water pumps, barometric condenser and ejector, condensate and flash tanks, hot well, etc.

Distillation unit. 304 SS complete with packed column, condenser, and reboiler.

Rotary vacuum filter $5 \mathrm{ft}$ dia $x$ $9 \mathrm{ft}$ wide, rubber lined steel, complete with filtrate receivers, filtrate pumps and vacuum pumps. 
CONCLUSIONS

The cost study showed the economic feasibility of producing REDOX chemicals on a commodity chemical scale for profitable sale at a costeffective price for the NASA REDOX Energy Storage System. Two potentially attractive processes were identified, methanol reduction of sodium chromate and chlorination of prereduced chrome ore. The methanol process is of greater immediate interest even though the other process may be potentially less costly, because its technical details are more completely understood and it should be more easily developed into a commercial process. Furthermore, the methanol process would have the versatility with minor modification of producing other commercially important chrome chemicals as well.

The projected selling price of REDOX chemicals by the methanol process, $\$ 1.26 / \mathrm{kg} \mathrm{CrCl} 3$, including $\mathrm{FeCl}_{2}$, corresponds to a specific energy storage cost of $\$ 11 / \mathrm{kWh}$. Projected storage cost for chemicals produced by the reductive chlorination process is under $\$ 9 / \mathrm{kWh}$. These results support the NASA REDOX system as a potentially economically feasible device for utility and other bulk storage applications.

Cost sensitivity analysis conducted on the methanol process showed that the price of REDOX chemicals by this process would be relatively little affected by changes in costs of individual raw materials and fuel. The process is capital intensive, but less so than the other processes, and a $25 \%$ change in capital costs would cause a $7 \%$ change in REDOX chemical price.

The scale of operation had a typical effect on selling price, ranging from $\$ 1.10 / \mathrm{kg}$ to $\$ 1.68 / \mathrm{kg}$ when the plant capacity decreased from 138000 metric tons $\mathrm{CrCl}_{3}$ per year to 27600 tons per year. 


\section{REFERENCES}

1. Thaller, L. H., "Recent Advances in Redox Flow Cell Storage Systems". Proceedings of the Fourteenth Intersociety Energy Conversion Engineering Conference, August 5-10, 1979; and private communications.

2. "Cost Projections for Redox Energy Storage Systems", Final Report. NASA CR-165260. NASA contract DEN3-126. Power Systems Division, United Technologies Corporation, February 1980.

3. Boericke, F.S. and Bangert, W.M., "Effect of Variables in Chemical Benefication of Chromite Ores". U.S. Bureau of Mines, R.I. 3817, July, 1945. 


\begin{tabular}{|c|c|c|c|}
\hline $\begin{array}{l}\text { 1. Report No. } \\
\text { NASA CR-167881 }\end{array}$ & 2. Government Accession No. & \multicolumn{2}{|c|}{ 3. Roclplent's Catalog No. } \\
\hline \multicolumn{2}{|c|}{ 4. Title and Subtitle } & \multicolumn{2}{|c|}{$\begin{array}{l}\text { 5. Report Date } \\
\text { November } 1982\end{array}$} \\
\hline \multicolumn{2}{|c|}{$\begin{array}{l}\text { Study to Establish Cost Projections for Production } \\
\text { of Redox Chemicals }\end{array}$} & \multicolumn{2}{|c|}{$\begin{array}{l}\text { 6. Performing Organization Code } \\
776-72-41\end{array}$} \\
\hline \multicolumn{2}{|c|}{$\begin{array}{l}\text { 7. Author(s) } \\
\text { J. F. Walther, C. C. Greco, R. N. Rusinko, and } \\
\text { A. L. Wadsworth, 3rd }\end{array}$} & \multicolumn{2}{|c|}{ 8. Performing Organization Report No. } \\
\hline \multicolumn{2}{|c|}{$\begin{array}{l}\text { 9. Performing Organizallon Name and Address } \\
\text { Syracuse Research Laboratory } \\
\text { All ied Chemical Company } \\
\text { P.0. Box } 6 \\
\text { Solvay, New York } 13209\end{array}$} & \multicolumn{2}{|c|}{$\begin{array}{l}\text { 11. Contract or Grant No. } \\
\text { DEN 3-250 }\end{array}$} \\
\hline \multicolumn{2}{|c|}{$\begin{array}{l}\text { 12. Sponsoring Agency Name and Address } \\
\text { U.S. Department of Energy } \\
\text { Division of Energy Storage Systems } \\
\text { Washington, D.C. } 20545\end{array}$} & \multicolumn{2}{|c|}{$\begin{array}{l}\text { 14. Sponsorling Agency-odopert No. } \\
\text { DOE/NASA/0250-1 }\end{array}$} \\
\hline \multicolumn{4}{|c|}{$\begin{array}{l}\text { 15. Supplementary Notes } \\
\text { Final Report. Prepared under Interagency Agreement DE-AI04-80AL12726. Project } \\
\text { Manager, R. F. Gahn, Solar and Electrochemistry Division, NASA Lewis Research } \\
\text { Center, Cleveland, Ohio } 44135 \text {. }\end{array}$} \\
\hline \multicolumn{4}{|c|}{$\begin{array}{l}\text { 16. Abstract } \\
\text { A cost study of four proposed manufacturing processes for redox chemicals for } \\
\text { the NASA REDOX Energy Storage System yielded favorable selling prices in the } \\
\text { range } \$ 0.99 \text { to } \$ 1.91 / \mathrm{kg} \text { of chromic chloride, anhydrous basis, including } \\
\text { ferrous chloride. The prices corresponded to specific energy storage costs } \\
\text { from under } \$ 9 \text { to } \$ 17 / \mathrm{kWh} \text {. A refined and expanded cost analysis of the most } \\
\text { favored process yielded a price estimate corresponding to a storage cost of } \\
\$ 11 / k W h \text {. The findings supported the potential economic viability of the } \\
\text { NASA REDOX system. }\end{array}$} \\
\hline $\begin{array}{l}\text { 17. Key Words (Suggestod by Author(s)) } \\
\text { Redox } \\
\text { Flow cells } \\
\text { Electrical energy storage } \\
\text { Load leveling } \\
\text { Chromic chloride }\end{array}$ & $\begin{array}{l}\text { 18. Distributlo } \\
\text { Unclas } \\
\text { STAR C } \\
\text { DOE Ca }\end{array}$ & $\begin{array}{l}d-\text { unlimited } \\
\text { ry } 44 \\
y \text { UC- } 94 \mathrm{cb}\end{array}$ & \\
\hline $\begin{array}{l}\text { 19. Security Classif. (of this report) } \\
\text { Unclassi fi ed }\end{array}$ & $\begin{array}{l}\text { 20. Security Classif. (of this page) } \\
\text { Unclassified }\end{array}$ & $\begin{array}{l}\text { 21. No. of pages } \\
38\end{array}$ & $\begin{array}{r}\text { 22. Price* } \\
\mathrm{A} 03\end{array}$ \\
\hline
\end{tabular}

* For sale by the National Technical Information Service, Springfield, Virginia 22161 
End of Document 